\title{
ПРО ДОСВІД ВПРОВАДЖЕННЯ СИСТЕМИ ЕЛЕКТРОННОГО ДОКУМЕНТООБІГУ У МЕДИЧНОМУ ВНЗ
}

\author{
А. В. Семенець, В. Ю. Ковалок \\ ДВНЗ «Тернопільський державний медичний університет імені І. Я. Горбачевського \\ МОЗ України»
}

У роботі показано актуальність впровадження моделі електронного документообігу в галузі охорони здоров'я України. Здійснено огляд ринку інформаційних систем електронного документообігу. Показано досвід використання вільно розповсюджуваних інформаційних систем електронного документообігу в ТДМУ. Продемонстровано можливості реалізації моделі електронного документообігу у вигляді хмарних сервісів. Зроблено порівняльний аналіз можливостей хмарних середовищ Microsoft Office 365, Google Apps For Education для їх застосування в якості систем електронного документообігу. Показано деякі результати застосування хмарного сервісу Google Apps For Education в ТДМУ.

Ключові слова: медичні інформаційні системи, електронний документообіг, система керування документами, програмне забезпечення з відкритим кодом, хмарні технологіï, Microsoft Office 365, Google Apps For Education.

\section{О ОПЫТЕ ВНЕДРЕНИЯ СИСТЕМЫ ЭЛЕКТРОННОГО ДОКУМЕНТООБОРОТА В МЕДИЦИНСКОМ ВУЗЕ}

\author{
А. В. Семенец, В. Ю. Ковалок \\ ГВУз «Тернопольский государственный медицинский университет \\ имени И. Я. Горбачевского МОЗ Украины»
}

\begin{abstract}
В работе показана актуальность внедрения модели электронного документооборота в области здравоохранения Украины. Осуществлен обзор рынка информационных систем электронного документооборота. Показан опыт использования свободо распространяемых информационных систем электронного документооборота в ТГМУ. Продемонстрированы возможности реализации модели электронного документооборота в виде облачных сервисов. Сделан сравнительный анализ возможностей облачных сред Microsoft Office 365, Google Apps For Education для их применения в качестве систем электронного документооборота. Показаны некоторые результаты применения облачного сервиса Google Apps For Education в ТГМУ.
\end{abstract}

Ключевые слова: медицинские информационные системы, электронный документооборот, система управления документами, программное обеспечение с открытым кодом, облачные технологии, Microsoft Office 365, Google Apps For Education.

\section{ON EXPERIENCE OF THE ELECTRONIC DOCUMENT MANAGEMENT SYSTEM IMPLEMENTATION IN THE MEDICAL UNIVERSITY}

\author{
A. V. Semenets, V. Yu. Kovalok \\ SHEI «Ternopil State Medical University by I. Ya. Horbachevsky of MPH of Ukraine»
}

An importance of the application of the electronic document management to the Ukraine healthcare is shown. The electronic document management systems market overview is presented. Example of the usage of the open-source electronic document management system in the Ternopil State Medical University by I. Ya. Horbachevsky is shown. The implementation capabilities of the electronic document management system within a cloud services are shown. The electronic document management features of the Microsoft Office 365 and Google Apps For Education are compared. Some results of the usage of the Google Apps For Education in TSMU as electronic document management system are presented.

Key words: medical information systems, electronic document management, document management system, opensource software, cloud technologies, Microsoft Office 365, Google Apps For Education.

(C) А. В. Семенець, В. Ю. Коваток 
Вступ. Інформатизація системи охорони здоров'я належить до числа ключових загальнодержавних завдань для України. Особливого значення набувають розробка та впровадження медичних інформаційних систем (МIC), які допомагають автоматизувати всі аспекти діяльності лікувальної установи [1]. Розробка МIC в розвинених країнах світу орієнтована на стандартизацію і обмін медичними даними (інтероперабельність) між різними ланками галузі охорони здоров'я. Стандартизація та інтероперабельність покращують ефективність роботи медичних закладів, допомагають лікарям уникати типових помилок, забезпечують економію часу медичних працівників i загалом покращують економічні показники системи охорони здоров' я [2].

Впровадження електронного документообігу в галузі охорони здоров'я Украӥни

Робота медичних працівників у значній мірі пов'язана з заповненням великої кількості документів на паперових носіях. Виконання такої роботи веде до значного витрачання робочого часу (за деякими оцінками - до 50 \%). Недоліки традиційного паперового документообігу в медицині описані в багатьох роботах, зокрема [3, 4].

Протягом останніх років органи державної влади України декларували суттєві заходи щодо питань автоматизації діловодства та документообігу в усіх сферах державного управління, в тому числі і в галузі охорони здоров' я [5-8]. В роботі [4] автор також наголошує, що одним 3 концептуальних напрямків впровадження сучасних інформаційних технологій у галузі охорони здоров'я $\epsilon$ формування моделі електронного документообігу (ЕДО).

Однак реальна ситуація саме в галузі охорони здоров'я свідчить про те, що більша частина перелічених урядових рішень або не виконується взагалі або містить серйозні прорахунки в процесі практичної реалізації, як описано в [4]. Особисті спостереження авторів свідчать, що впровадження ЕДО в установах галузі охорони здоров'я України на сьогодні мають епізодичний і випадковий характер. Це дуже прикро, бо правильне запровадження таких МІС суттєво полегшує роботу адміністрації медичного закладу. Можливість централізованого доступу до адміністративних документів та контролю за їх виконанням зазвичай суттєво підвищує якість та ефективність управлінських рішень. Фактично, виняток складає лише центральний апарат МО3 України, в якому запроваджена і функціонує досить сучасна інформаційна система ЕДО [9].
Короткий огляд ринку інформаційних систем електронного документообігу

Процес широкого запровадження моделі електронного документообігу в усіх галузях економіки та сферах державного управління розвинених країн розпочався ще кілька десятиліть тому. Наслідком є розвинений і конкурентний ринок інформаційних систем електронного документообігу (IC ЕДО) різного виду - як комерційного, так і з відкритим кодом, що орієнтовані на потреби різнотипних замовників - від невеликих офісів до транснаціональних корпорацій. Найбільшими розробниками комерційних IC ЕДО є компанії EMC, IBM, Microsoft, OpenText, НР та Хеrox.

Процес інтеграції пострадянських країн у світовий економічний простір ініціював, серед іншого, і хвилю розробки нових IC ЕДО, адаптованих до особливостей економіки, діловодства і методів державного управління [10]. Серед таких розробок набули великого поширення такі IC ЕДО як: ДЕЛО, LANDOCS, SharePoint Portal Server, Optima-Workflow, БOCCРеферент, Свфрат, Documentum [11]. Окремо виділяється спеціалізована конфігурація " $1 \mathrm{C}$ : Предприятие" під назвою "1С: Документооборот 8" (http:/ 1c.abbyy.ua/products/1c8/docflow/). Серед багатьох позитивних якостей даної ІС ЕДО слід відмітити хорошу адаптацію до вимог законодавства України.

Велика різноманітність доступних рішень в галузі ЕДО створила ринок спеціалізованих консультативних послуг з порівняння та підбору оптимальної IC ЕДО залежно від особливостей бізнесу. Останні зараз все частіше надаються у вигляді онлайнсервісів, як комерційних так і безкоштовних, наприклад $[12,13]$. Регулярно публікуеться велика кількість оглядів та аналітичних досліджень, що покликані допомогти у виборі оптимального рішення при впровадженні IC ЕДО [14-16]. Слід підкреслити, що аналіз ринку IC ЕДО зараз є серйозним та прибутковим напрямком бізнесу з високою вартістю інформації [17]. Окремо слід зазначити роботу [18], в якій автори проаналізували IC ЕДО з точки зору особливостей застосування у наукових та освітніх закладах України.

Важливо також відзначити сучасний напрямок впровадження ЕДО, що полягає у використанні хмарних сервісів для організації колективної роботи в рамках парадигми "Програмне забезпечення як послуга (Software as a Service, SaaS)' $[19,20]$. Цей підхід є одним з найефективніших на сьогоднішній день, особливо в умовах складної економічної ситуації, яка спостерігається зараз в Україні і має значний негативний вплив на галузь освіти і науки. 
Основною метою роботи $є$ огляд можливостей окремих сучасних інформаційних систем та хмарних сервісів щодо забезпечення функціонування IC ЕДО освітнього закладу на основі досвіду Тернопільського медичного університету імені I. Я. Горбачевського.

Досвід ТДМУ з впровадження ІС ЕДО в медичній освіті

Починаючи з 2005 року в навчальний процес ТДМУ регулярно запроваджуються нові методики та підходи до підготовки майбутніх спеціалістів. Більша частина вказаних інновацій грунтується на використанні цілого ряду інформаційних технологій та ресурсів [21]. Протягом 2013 року, з ініціативи та за активної участі авторів роботи, було здійснено реорганізацію інформаційної інфраструктури ТДМУ для приведення іï у відповідність до вимог сучасності [22]. Одинз кроків реорганізації передбачав впровадження IC ЕДО. Основними критеріями вибору IC ЕДО були:

1. Безкоштовна ліцензія для закладів освіти або належність до вільно розповсюджуваного ПЗ.

2. Невеликі системні вимоги до обладнання.

3. Простота розгортання та адміністрування.

Застосування IC "Alfresco"

Серед ПЗ з відкритим кодом на ринку IC ЕДО безперечним лідером є IC "Alfresco" (http:// www.alfresco.com/). Вибору даної системи в якості IC ЕДО для потреб ТДМУ сприяли наступні фактори:

1. Наявність безкоштовної, вільно розповсюджуваної версії 3 відкритим кодом (http:// www.alfresco.com/community).

2. Функціональні можливості безкоптовної версії не поступаються, а в багатьох аспектах - і перевершують - відповідні у деяких комерційних продуктів (наприклад "1С: Документооборот 8").

3. Невеликі початкові системні вимоги та хороша масштабованість.

4. Якісна документація (завдяки наявності комерційної версії).

Розробник позиціонує IC "Alfresco" як ЕСМ-систему (Enterprise content management), що поєднує функціонал IC ЕДО, засоби спільної роботи з документами та платформу для інтегрованого корпоративного веб-порталу в єдине ціле.

Процес запровадження IC “Alfresco" в ТДМУ розпочався в квітні 2013 року. IC було розгорнуто на віртуальному сервері в мережевому кластері ТДМУ [22]. План впровадження передбачав тестову експлуатацію в інформаційно-аналітичному відділі ТДМУ 3 метою:
- отримання працівниками практичних навичок використання та адміністрування даної IC;

- розробки методичних рекомендацій щодо впровадження даної IC в інших підрозділах університету.

Тестова експлуатація IC “Alfresco” в інформаційно-аналітичному відділі ТДМУ тривала до квітня 2014 року. Отримано наступні результати:

1. Накопичено близько 5 тис. документів (переважна більшість - в форматах MS Office) середнім обсягом 1-2 Мб. Загальний обсяг репозиторію близько $400 \mathrm{Mб.}$

2. Розроблено методику застосування в практичній діяльності інформаційно аналітичного відділу ТДМУ таких функціï IC “Alfresco" як використання репозиторію документів, робота з календарем, використання механізму завдань.

3. Вивчено базові прийоми та методики адміністрування IC "Alfresco".

4. Встановлено ряд негативних факторів, зокрема:

- складність розширеного адміністрування IC "Alfresco", наприклад, при конфігуруванні доступу по протоколу WebDAV або при налаштуванні вбудованого корпоративного веб-порталу;

- висока чутливість IC “Alfresco" до збоїв в роботі апаратного забезпечення (наприклад, як наслідок перебоїв енергопостачання).

На основі вищевказаного було прийнято рішення про пошук альтернативних рішень щодо формування ЕДО. При виборі особлива увага повинна приділятися питанням простоти розгортання і адміністрування, високої стабільності роботи та простоти відновлення після перебоїв.

Альтернативні вільно розповсоджсувані платформи ЕДО: ОрепКМ ма Nuхео

Як було вказано раніше, існує велика кількість рішень IC ЕДО. В якості альтернативних платформ ЕДО авторами було випробувано такі IC як ОреnКМ (http://www.openkm.com/) та Nuxeo (http:// www.nuxeo.com/).

В даному випадку пробна експлуатація не проводилася. Авторами здійснювалося лише тестове встановлення з практичним вивченням основного функціоналу, складності адміністрування, реальних системних вимог ІС ЕДО.

В результаті тестування вказаних IC ЕДО отримано такі головні результати:

1. Процес розгортання обох систем помірно складний і мало відрізняється від процесу розгортання IC "Alfresco". 
2. Поточна версія IC OpenKM (5.1 на момент тестування) працює нестабільно, з багатьма перебоями

3. Функціональні можливості IC Nuxeo перевищують відповідні в IC OpenKM.

4. Складність адміністрування обох IC знаходиться приблизно на однаковому, доволі високому рівні.

5. Обидві системи так само чутливі до перебоїв в роботі апаратного забезпечення, як і IC "Alfresco".

В результаті авторами було прийнято рішення щодо нераціональності використання IC OpenKM та Nuxeo через однотипні з IC "Alfresco" проблеми.

Застосування хиарних сервісів ЕДО в ТДМУ

Виходячиз вищевказаного, застосування хмарних сервісів для цілей ЕДО є раціональним рішенням. Основні конщепції побудови ІС ЕДО у вигляді хмарного сервісу ЕДО показано в роботі [19]. Порівняльний аналіз окремих спеціалізованих хмарних сервісів ЕДО наведено в роботах $[17,20]$. Станом на початок 2014 року всі провідні розробники десктопних IC ЕДО (див. п. 2) пропонують також власні хмарні сервіси. Однак вказані спеціалізовані хмарні сервісиЕДО є виключно комерційними $і$ їх послуги надаються лите на платній основі.

Сдиний виняток становлять такі хмарні сервіси як Microsoft Office 365 (http://office.microsoft.com/) та Google Apps For Education (http://www.google.com/ enterprise/apps/education/), які надають безкоштовний доступ для навчальних закладів. Порівняльний аналіз можливостей вказаних хмарних сервісів наведено в роботі [23]. Підходи щодо застосування обох сервісів в якості IC ЕДО наведено в роботах [23-25].

Слід зазначити, що автори розпочали ініціативне впровадження Microsoft Office 365 та Google Apps For Education в ТДМУ протягом 2013 р. Основні напрямки застосування даних хмарних сервісів у навчальному процесі ТДМУ станом на початок 2014 року показано в роботі [26]. Першочерговими пріоритетами було проведення відеонарад з використанням сервісу Lync Online з пакету Microsoft Office 365 та використання корпоративного поштового сервісу з пакета Groogle Apps For Education.

Порівняльні результати аналізу можливостей обох вказаних хмарних сервісів щодо реалізації ЕДО на основі робіт [23-25, 27] та власного досвіду авторів показано далі (табл. 1).

Таблиця 1. Порівняльні можливості хмарних сервісів Microsoft Office 365 та Google Apps For Education

\begin{tabular}{|c|c|c|c|}
\hline Функціонал & Office 365 & Google Apps & Примітки \\
\hline 1 & 2 & 3 & 4 \\
\hline Кількість користувачів & Необмежено & Необмежено & \\
\hline Вартість ліцензії & $\begin{array}{c}\text { 1. Безкоштовно для } \\
\text { навчальних закладів } \\
\text { (план A2) } \\
2 . \$ 2.50 / \$ 4.50-\text { план A3 }\end{array}$ & $\begin{array}{c}\text { Безкоштовно для навчальних } \\
\text { закладів }\end{array}$ & $\begin{array}{l}\text { План А3 включає } \\
\text { ліцензію на десктопне } \\
\text { ПЗ Office Professional }\end{array}$ \\
\hline $\begin{array}{l}\text { Поштовий сервіс (обсяг } \\
\text { скриньки) }\end{array}$ & $\begin{array}{l}\text { Exchange } \\
50 \Gamma \sigma\end{array}$ & $\begin{array}{l}\text { Gmail } \\
30 Г б\end{array}$ & \multirow[t]{4}{*}{$\begin{array}{l}\text { Функціональні } \\
\text { можливості зіставні }\end{array}$} \\
\hline - Контакти & + & + & \\
\hline - Календар & + & + & \\
\hline - Задачі & + & $\begin{array}{c}\text { + (додаткова функціональність } \\
3 \text { Podio App) }\end{array}$ & \\
\hline $\begin{array}{l}\text { Сервіс зберігання файлів } \\
\text { (обсяг) }\end{array}$ & $\begin{array}{l}\text { MS One Drive } \\
1 \text { Тб }\end{array}$ & $\begin{array}{l}\text { Google Drive } \\
20 Г б\end{array}$ & \multirow[t]{3}{*}{$\begin{array}{l}\text { Функціональні } \\
\text { можливості зіставні }\end{array}$} \\
\hline - Синхронізація з ПК & MS SkyDrive Pro & Google Disk & \\
\hline $\begin{array}{l}\text { - Підтримка мобільних } \\
\text { пристроїв } \\
\end{array}$ & $\begin{array}{l}\text { Підтримуються всі } \\
\text { основні платформи }\end{array}$ & $\begin{array}{c}\text { Підтримуються всі основні } \\
\text { Платформи }\end{array}$ & \\
\hline - Робота в браузері & $\begin{array}{l}\text { Повнофункційні Word, } \\
\text { Excel, PowerPoint }\end{array}$ & $\begin{array}{c}\text { Сумісні Docs, Spreadsheets, } \\
\text { Presentations }\end{array}$ & $\begin{array}{l}\text { Просунуті функції } \\
\text { кращі в Office } 365\end{array}$ \\
\hline - Настільне ПЗ & $\begin{array}{l}\text { Відмінно: } \\
\text { Office Professional }\end{array}$ & $\begin{array}{l}\text { Обмежено: } \\
\text { Chrome offline }\end{array}$ & \\
\hline - Сумісність документів & Відмінно & Задовільно & \multirow{2}{*}{$\begin{array}{l}\text { Google Drive } \\
\text { простіший у } \\
\text { застосуванні }\end{array}$} \\
\hline $\begin{array}{l}-\quad \text { Спільна робота } 3 \\
\text { документами }\end{array}$ & Відмінно & Відмінно & \\
\hline
\end{tabular}


Продовження табл. 1

\begin{tabular}{|c|c|c|c|}
\hline 1 & 2 & 3 & 4 \\
\hline Корпоративний портал & MS Sharepoint & Google Sites & \multirow{3}{*}{$\begin{array}{l}\text { Функціональність MS } \\
\text { Sharepoint на порядок } \\
\text { вища }\end{array}$} \\
\hline - Налаштування & Складно & Просто & \\
\hline - Спільна робота & + & + & \\
\hline Відеозв'язок & MS Lync & Google Hangouts & \multirow{5}{*}{$\begin{array}{l}\text { Функціональність } \\
\text { зіставна. } \\
\text { Однак MS Lync } \\
\text { підтримує на порядок } \\
\text { більше число } \\
\text { учасників } \\
\end{array}$} \\
\hline - Кількість учасників & До 250 & До 15 & \\
\hline - $\quad$ Планування нарад & + & + & \\
\hline - Обмін файлами, повідомлення & + & + & \\
\hline - $\quad$ Доступ до робочого столу & + & + & \\
\hline - Запис відео & + & + (через Youtube) & \\
\hline $\begin{array}{l}\text { Надійність (за даними } \\
\text { постачальника) }\end{array}$ & $99,90 \%$ & $99,90 \%$ & \multirow[t]{2}{*}{ Параметри зіставні } \\
\hline Засоби підтримки, режим роботи & $\begin{array}{c}\text { Ел. пошта, телефон } \\
24 * 7 * 365 \\
\end{array}$ & $\begin{array}{c}\text { Ел. пошта, телефон } \\
24 * 7 * 365\end{array}$ & \\
\hline
\end{tabular}

На основі проведеного аналізу було прийнято рішення про використання Google Apps For Education в якості основної платформи ЕДО в ТДМУ. Основним критерієм, який дозволив зробити остаточний вибір, стала саме простота адміністрування. Однак безкоштовний характер ліцензій для обох продуктів дозволяє продовжувати використовувати окремі сервіси Microsoft Office 365, в першу чергу Lync-оскільки можливості Google Hangouts $\epsilon$ недостатніми для потреб ТДМУ.

На виконання прийнятого рішення, у квітні 2014 авторами було здійснено перенесення документації аналітичного відділу з сервера IC “Alfresco" в Google Drive. Також, на основі матеріалів робіт $[24,25,28]$ розроблено рекомендації для управлінського персоналу щодо ведення документообігу з використанням можливостей сервісу Google Apps For Education. Діаграми (рис. 1, 2) ілюструють суттєве кількісне зростання обсягів документації ТДМУ, яка зберігається та обробляється з використанням можливостей сервicy Google Drive станом на вересень 2014 року. Негативним фактором, однак, $\epsilon$ відносно невелике число активних користувачів сервісу Google Drive в ТДМУ.

Якісні зміни в процесі діловодства вимагають більш тривалого часу та не лише накопичення "критичної маси" електронних документів, а й розширення переліку активних користувачів хмарних сервісів.

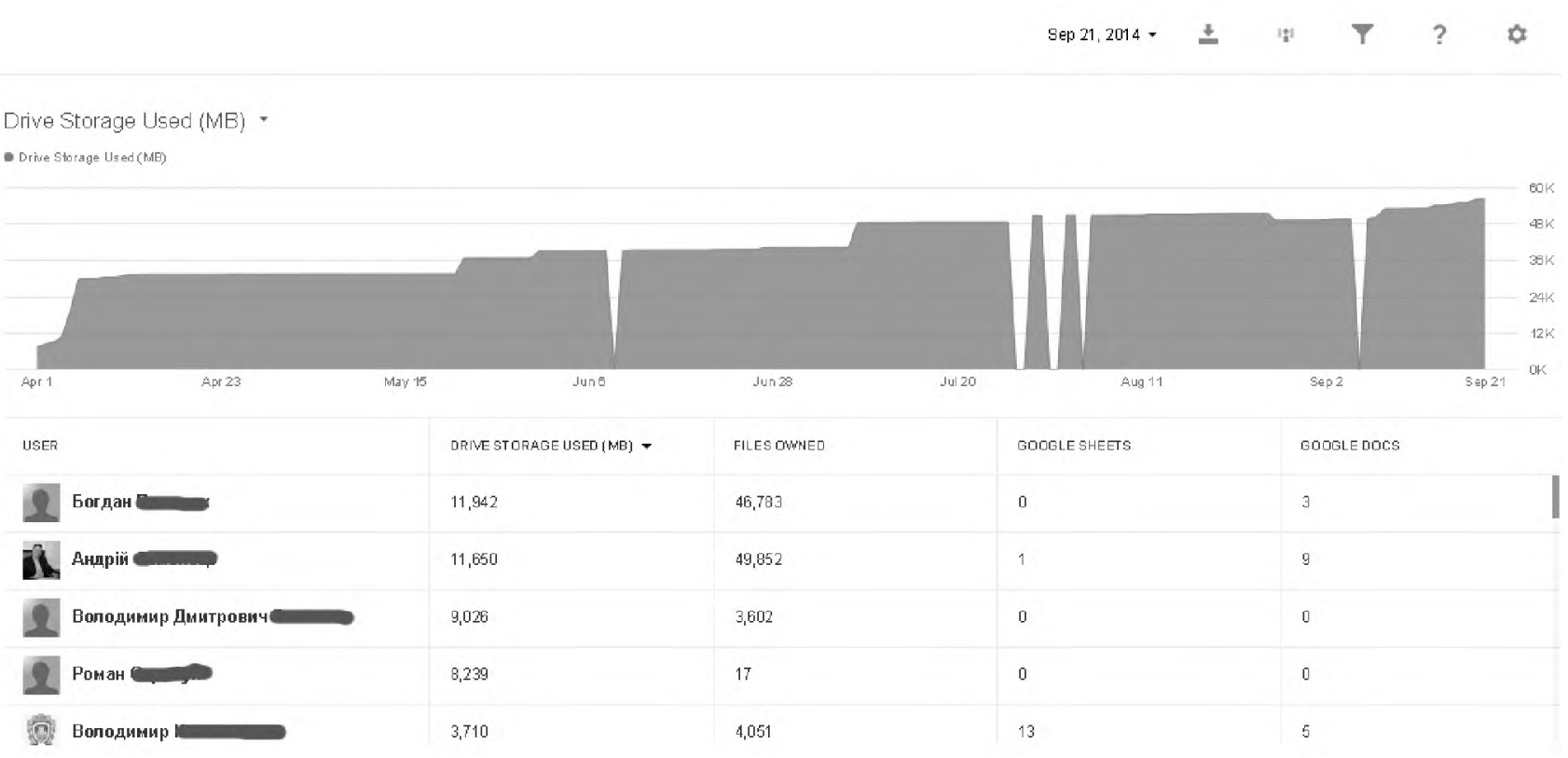

Puc. 1 . Графік росту використання обсягу дискового простору в сервісі Google Drive ТДМУ протягом 2-3 кварталу 2014 року. 


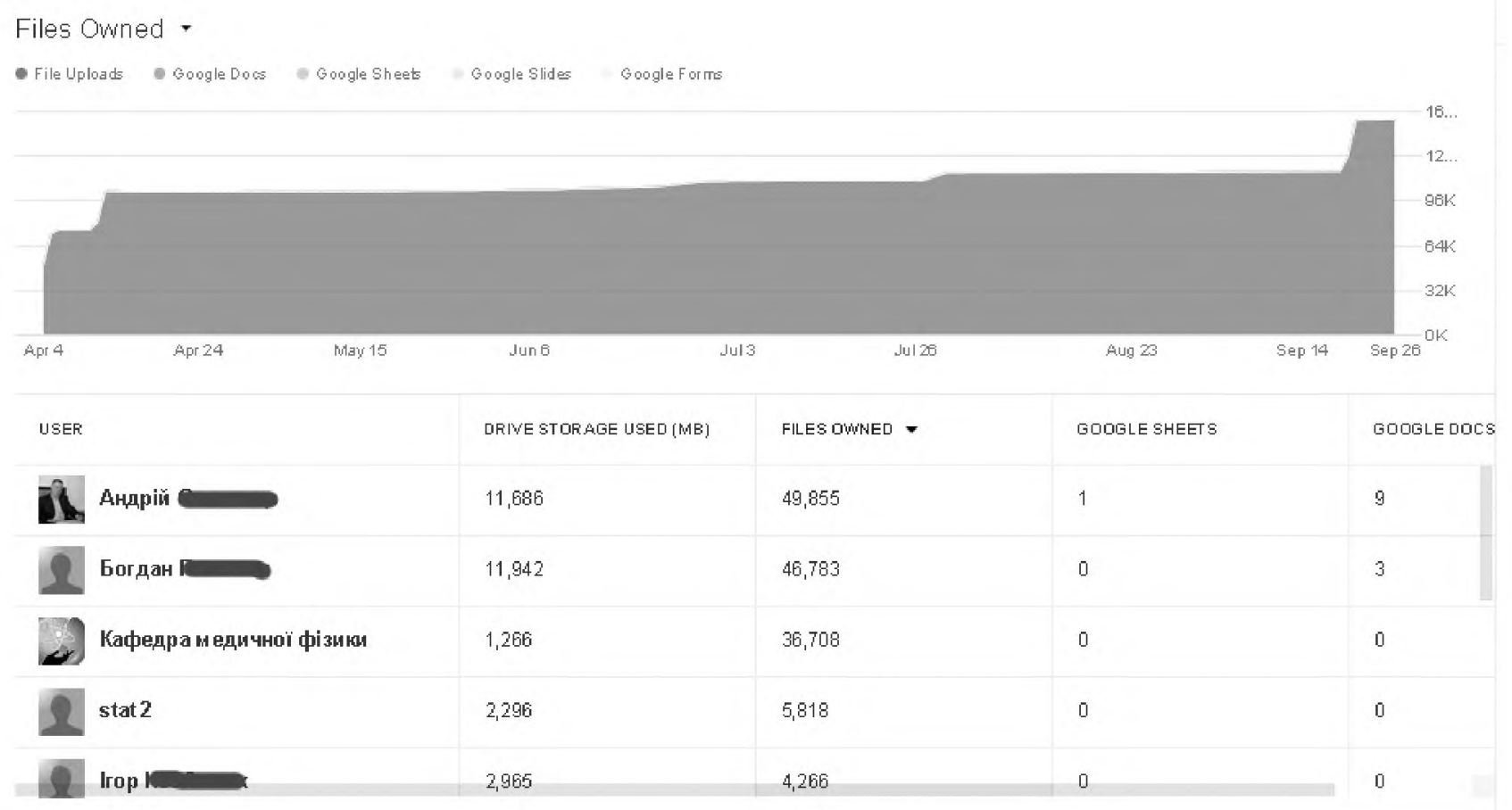

Puc. 2. Графік росту числа файлів, завантажених у сервіс Google Drive ТДМУ протягом 2-3 кварталу 2014 року.

Висновки. ШІироке впровадження інформаційних технологій у поєднанні з організаційними змінами в медичних лікувальних та навчальних закладах дозволить суттєво підвищити ефективність роботи закладів охорони здоров'я, підвищити якість лікування, діагностики та медичної освіти. Впровадження моделі електронного документообігу - необхідна умова підвищення якості управлінських рішень в закладах галузі охорони здоров'я та медичної освіти.

У роботі авторами показано можливості реалізації моделі електронного документообігу у медичному ВНЗ з використанням різних підходів:

1. Використання спеціалізованого комерційного П3 ІС ЕДО.

2. Запровадження та адаптація вільно розповсюджуваного ПЗ ІС ЕДО.

3. Використання спеціалізованих хмарних сервісів від провідних постачальників послуг ЕДО.

4. Реалізація моделі ЕДО на основі хмарних сервісів загального призначення в рамках академічних програм.

\section{Література}

1. Качмар В. О. Медичні інформаційні системи - стан розвитку в Україні / В. О. Качмар // Український журнал телемедицини та медичної телематики. - 2010. - Т. 8, № 1. C. $67-73$.
Авторами показано, що реалізація підходів 1 та 2 вимагає суттєвих фінансових затрат для закупівлі обладнання та ПЗ (у випадку 1), а також наявності в лікувальному закладі чи ВНЗ штату висококваліфікованих системних адміністраторів. Проте реалізація підходів 3 та 4 вимагає суттєво менших фінансових затрат. В першу чергу зменшуються (чи повністю відсутні) витрати на обладнання. Крім того, застосування хмарних сервісів не вимагає такої високої кваліфікації адміністративного персоналу. Особливу перевагу при побудові ЕДО у вигляді “хмари" мають медичні ВНЗ, завдяки повністю безкоштовному доступу до провідних хмарних сервісів Microsoft Office 365 та Google Apps For Education.

Як приклад авторами показано досвід реалізації моделі ЕДО в ТДМУ, що включає застосування вільно розповсюджуваної IC "Alfresco" на першому етапі автоматизації діловодства, з наступною міграцією користувачів та документів у хмарний сервіс Google Apps For Education на даний час.

2. Авраменко В. I. Формування основних напрямків розвитку інформаційних технологій в охороні здоров'я України на основі світових тенденщій / В. І. Авраменко, В. О. Качмар // Український журнал телемедицини та медичної телематики. -2011 . - Т. 9, № 2. - С. 5-15. 
3. Хвишун А. І. Принципи формування сдиної медичної інформаційної системи великого міста / А. І. Хвищун, В. О. Качмар // Медична інформатика та інженерія. -2009. № 3. - С. 39- 47.

4. Семенець А. В. Організаційно-методичні підходи впровадження EMR-систем в охороні здоров'я України / А. В. Семенець // Медична інформатика та інженерія. 2013. - № 3.- C. 35-43.

5. Закон України Документ 74/98-вр, чинний, поточна редакція-Редакція від 30.07.2010, підстава 2289-17. «Про Національну програму інформатизації». [Електронний ресурс]. - Режим доступу: http://zakon2.rada.gov.ua/laws/ show $/ 74 / 98-\% \mathrm{D} 0 \% \mathrm{~B} 2 \% \mathrm{D} 1 \% 80$;

6. Закон України № 851-15, чинний, поточна редакщія - Редакція від 24.06.2005, підстава 2599-15. «Про електронні документи та електронний документообігу. [Електронний pecypc]. - Режим доступу: http://zakon1.rada.gov.ua/laws/ show/851-15;

7. Розпорядження Кабінету Міністрів України від 13.12.2010 № 2250 «Про схвалення Конщепщії розвитку електронного урядування в Україні». [Електронний ресурс]. - Режим доступу: http://document.ua/pro-shvalennja-koncepciyirozvitku-elektronnogo-urjaduvannja-doc40786.html;

8. Розпорядження Кабінету Міністрів України від 28.12.2011 № 1363 «Питання впровадженшя системи електронної взаємодії органів виконавчої влади». [Електронний ресурс]. Режим доступу: http://zakon4.rada.gov.ua/laws/show/13632011-\%D1\%80;

9. Наказ МОЗ України від 25.09.2012 № 742 "Про оновлену Систему електронного документообігу у центральному апараті MO3 України". [Електронний ресурс]. - Режим доступу: http://www.moz.gov.ua/ua/portal/ dn 20120925_742.html;

10. Електронне діловодство [Текст] : [монографія]/ А. О. Мелащенко, О. С. Скарлат; Нац. акад. наук України, Ін-т кібернетики ім. В. М. Глушкова. - К. : Наукова думка, 2013. $-138 \mathrm{c}$.

11. Гарасим О. Р. Аналіз засобів управління корпоративною конфіденційною інформацією/ О. Р. Гарасим, Л. Б. Чирун // Інформаційні системи та мережі // Вісник Національного університету «Львівська політехніка). - 2010. № 689.-C. 117-128.

12. Document Management Comparison. [Електронний peсурс]. - Режим доступу: http://documentmanagementsoftware.org/find-product ;

13. Compare Document Management Software. [Електронний pecypc]. - Режим доступу: http://documentmanagement.findthebest.com/ ;

14. Обзор систем электронного документооборота. [Електронний ресурс]. - Режим доступу: http://www.financetimes.ru/newscompany/16360/;

15. DG Internal Market and Service DG Enterprise and Industry "Final Report of the Expert group on e-Invocing". - November 2009. [Електронний ресурс]. - Режим доступу: http:// ec.europa.eu/internal_market/consultations/docs/2009/einvoicing/report_en.pdf;
16. Comparison OfDocument Management Systems By Meta Modelling And Workforce Centric Tuning Measures. International Journal of Computer Science, Engineering and Information Technology (IJCSEIT). - 2014. - Vol. 4, № 1.P. 35-46.

17. Global Document Management Systems (DMS) Market 2014-2018. [Електронший ресурс]. - Режим доступу: http:// www.researchandmarkets. co m/research/hd 8 trq/ global document

18. Поліновський В. В. Впровадження системи електронного документообігу в науковій організації / В. В. Поліновський, М. І. Огурцов // Вісник Хмельницького національного університету. -2010.--№ 4.-С. 117-123.

19. Mark Rodholm, Cloud-Based Document Management. [Електронний ресурс]. - Режим доступу: http:// www.acpitsolutions.com/document-management/cloudbased-document-management/;

20. Veronica MezaT., Cloud Document Management Software: Comparing the Top Solutions. [Електронний pecypc]. - Peжим доступу: http:/smartdocumentmanagement.athento.com/ 2012/05/cloud-document-management-software.html ;

21. Ковальчук Л. Я. Впровадження в навчальний процес комп'ютерних технологій / Л. Я. Ковальчук, В. П. Марценюк // Медична інформатика та інженерія. -2008. - № 1.C. $14-16$.

22. Семенець А. В. Концепція побудови інформаційної інфраструктури медичного ВНЗ з використанням вільно розповсюджуваного програмного забезпечення з відкритим кодом/ А. В. Семенець, В.Ю.Ковалок// Інформаційні технології і засоби навчання. - 2014. - № 3. - С. 277-288.

23. Ian Hardenburgh, GoogleApps v. Office 365: Content and document management. [Електронний ресурс]. - Режим доступу: http://www.techrepublic.com/blog/the-enterprisecloud/google-apps-v-office-365-content-and-documentmanagement/;

24. Karl Hedstrom, Google Drive as an Organizational Document Management System: an NTEN Case Study. [Електронний ресурс]. - Режим доступу: http://www.nten.org/ articles/2013/google-drive-as-an-organizational-documentmanagement-system-an-nten-case-study ;

25. Brian Loebig, Low Cost Document Management | Google Drive. [Електронний ресурс]. - Режим доступу: http:// theinkblog.net/2013/01/10/low-cost-document-managementgoogle-drive/ ;

26. Семенець А. В. Застосування хмарних технологій при побудові інформаційної інфраструктури медичного ВНЗ / А. В. Семенець // Медична освіта. -2014. - № 1. - С. 99 104.

27. Бельтриков Ю. Выбор «облачной» платформы для офнca: Office 365 или Google Apps [Електронний ресурс]. Режим доступу: http://netlly.ru/office365-vs-google-apps/ 28. Podio for GoogleApps - Collaborative Workflow from Email $\&$ Docs / [Електронний ресурс] - Режим доступу до документа : https://www.google.com/enterprise/marketplace/view Listing?productListingld $=14868+5457825895916594912$ \&pli $=1$ 